\title{
NUMERICAL ANALYSIS OF STRESS AND STRAIN PATTERN \\ OCCURING IN THE CONTACT AREA OF COOPERATING ELEMENTS OF HIP AND KNEE JOINT ENDOPROSTHESES
}

\author{
Michat Sobociński, Marcin Nabrdalik \\ Institute of Mechanical Technology, Czestochowa University of Technology \\ Czestochowa, Poland \\ sobocinski@iop.pcz.pl,marcin@iop.pcz.pl
}

\begin{abstract}
The paper presents the numerical analysis of stress and strain occuring in the most wearable parts of hip and knee joint endoprostheses. In the hip joint that would be the pair: the head - cup, and in the knee joint: sled - insert. The complexity of the processes taking place both in natural and artificial joint make is necessary to conduct the analysis on the 3D model and basing on already existing mathematical models. Finite elements method makes it possible to calculate the stress in particular elements of the tested model.
\end{abstract}

\section{Numerical analysis of stress and strain occuring in the hip joint endoprostheses}

The finite elements method enables one to calculate the stresses in respective parts of the analytical model.

In available publications there have been presented the results of numerical analysis of hip joint endoprosthesis in model 2D [1,2]. Due to complexity of proceeding equally in natural and artificial hip it is critical to make an analysis in model 3D $[3,4]$.

It is currently very popular to offer endoprostheses with a replacable cap in metal casing. This solution allows one to decrease the operating area that the patient has to be subjected to when the endoprosthesis' parts get worn. The cups and casing are most commonly made of the alloy Ti6Al4V and an appropriate insert. The replaceable internal element can be made of UHMWPE [5], bioceramics [6] or - like in the most recent solutions - double-layer materials [7].

The model is based on dimensions of a real modular cup and endoprosthesis head of AESCULAP Corp. offered by Plasmacup SC. A numerical analysis was conducted on the ADINA program System 7.5.1. The geometrical model was elaborated basing on measurements of real cups and heads and on data pointed in the catalogue by the producer [8]. The solid model was made directly in program ADINA System 7.5.1.

Due to difficult modeling of connection „cup casing - bone”, the contact area was simplified to a common edge [9]. Technological holes, which are usually used 
for placing the cap during implantation, were omitted, as they cause stress concentration in the observed model.

The discreet model view of the solution being elaborated in shown in Figure 1.

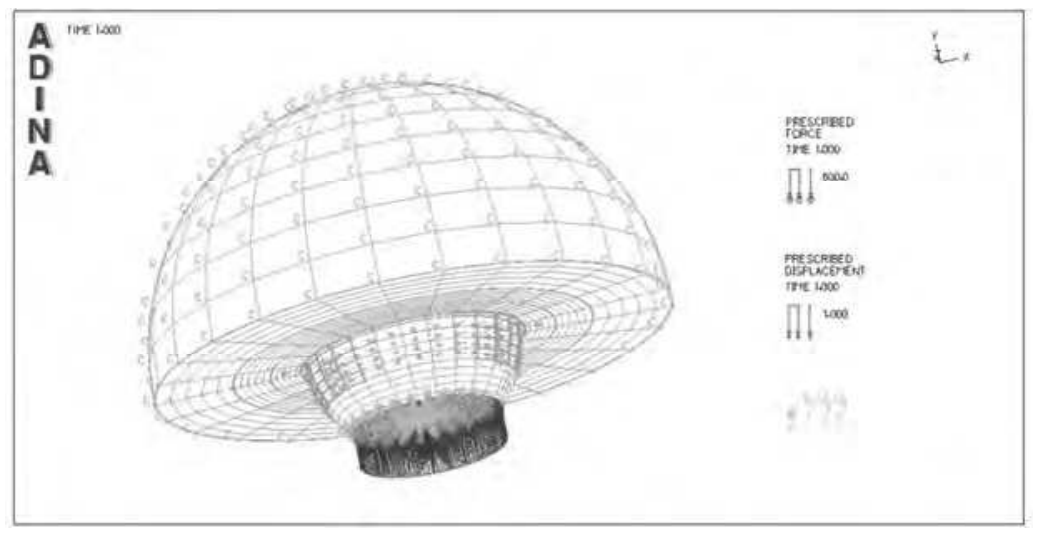

Fig. 1. The discreet model view of the solution being elaborated

The material model of the set ,joint head - cup" was elaborated based on available experimental tests results concerning mechanical features of bone structures and of implantation materials [10-12]. Simulations do no cover mechanical anisotropy non-viscoelasticity of bone tissues.

All cases are considered bone tissue as elastic isotopic material. The analytical models covered the following kinds of materials used for production of "head cup" systems in the hip joint endoprotshesis: titanium alloy Ti6Al4V, alloy CoCrMo, ceramics $\mathrm{Al}_{2} \mathrm{O}_{3}$.

Strenght parameters of the materials and bone tissue used in analysis are presented in Table 1.

Table 1

Mechanical features of biomaterials and bone tissue

\begin{tabular}{|c|c|c|}
\hline Element of the model & Young's module $[\mathrm{MPa}]$ & Poisson's coefficient $v$ \\
\hline Core bone & $1.7 \times 10^{4}$ & 0.35 \\
\hline Alloy CoCrMo & $2.0 \times 10^{5}$ & 0.3 \\
\hline Alloy Ti6Al4V & $1.1 \times 10^{5}$ & 0.3 \\
\hline UHMWPE & $1.0 \times 10^{3}$ & 0.4 \\
\hline Ceramics $\mathrm{Al}_{2} \mathrm{O}_{3}$ & $3.8 \times 10^{5}$ & 0.22 \\
\hline
\end{tabular}

The paper presents three discrete models of „endoprosthesis head - cup” system for three material collocations:

- Metal head CoCrMo - cup UHMWPE,

- Ceramic head - cup UHMWPE,

- Ceramic head - ceramic cup. 
In all cases on the surface of the contact area between the endoprosthesis head and internal surface of cup, the contact elements have been generated of the 3D contact type. Each set covered the load respective to the load strength put onto endoprosthesis head on the plane XY and equal 600 and $1500 \mathrm{~N}$. The analysed model was placed stiffly on the external surface respective to the external surface of bone tissue surrounding the implant.

Figure 2 presents the stress pattern $\sigma_{\mathrm{zr}}$ of the analysed set for: head CoCrMo cup UHMWPE.

Figure 3 presents the strain distribution of the analysed set for: head CoCrMo cup UHMWPE. Maximum stress values occuring in particular elements of set „head - cup - casing - bone” is presented in Figure 4.

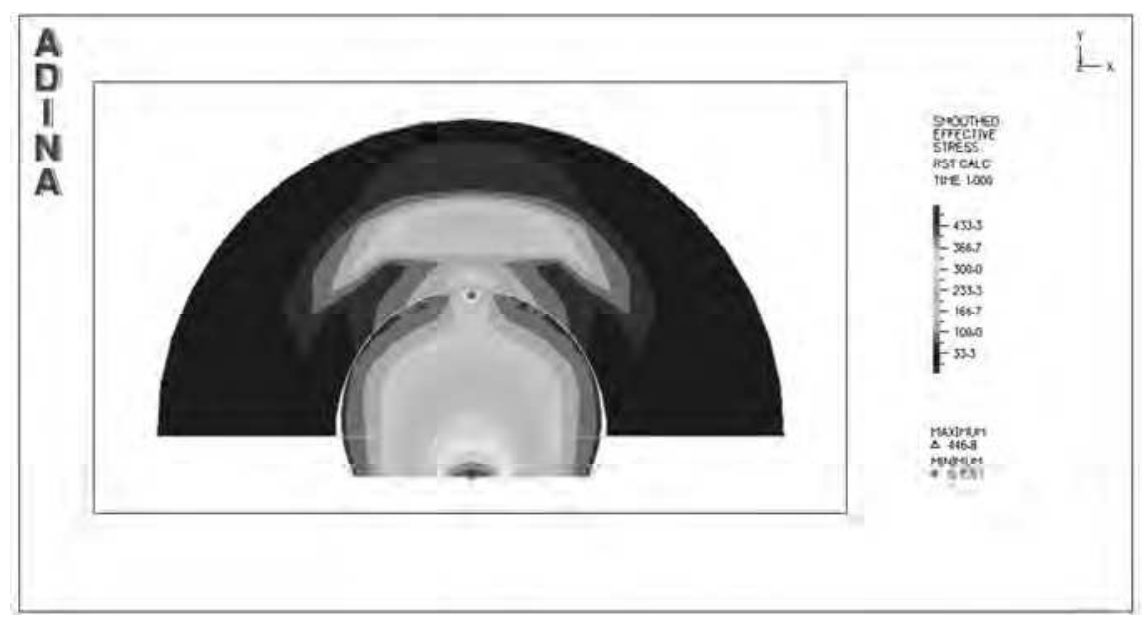

Fig. 2. Stress pattern $\sigma_{\mathrm{zr}}[\mathrm{MPa}]$ in cross-section of the analysed set for: head CoCrMo - cup UHMWPE, with load $600 \mathrm{~N}$

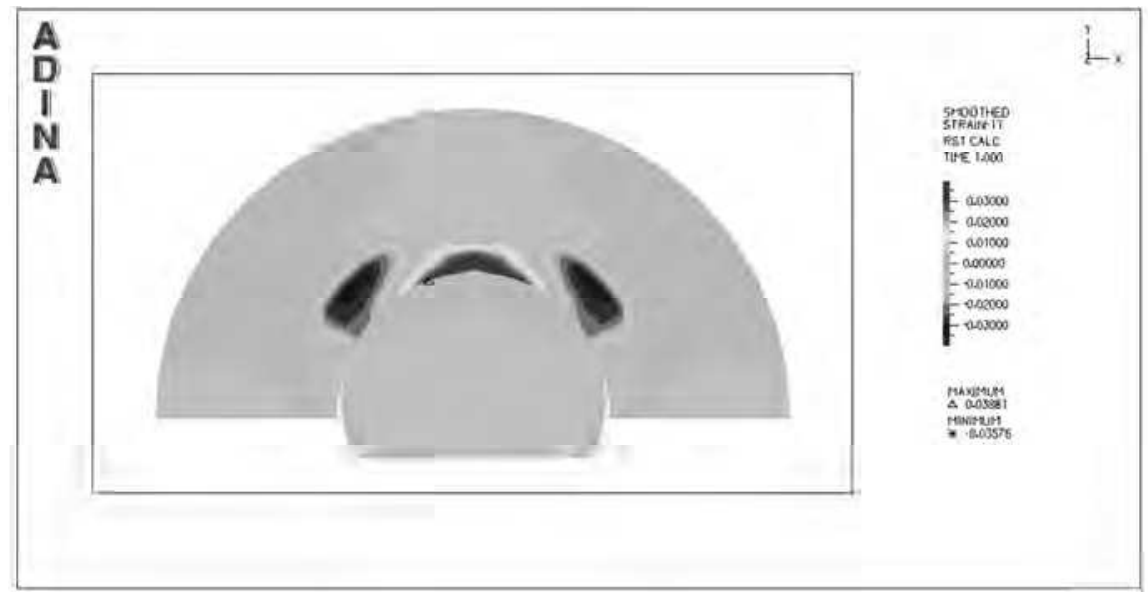

Fig. 3. Strain distribution in cross-section of the analysed set for: head CoCrMo - cup UHMWPE, with load $600 \mathrm{~N}$ 


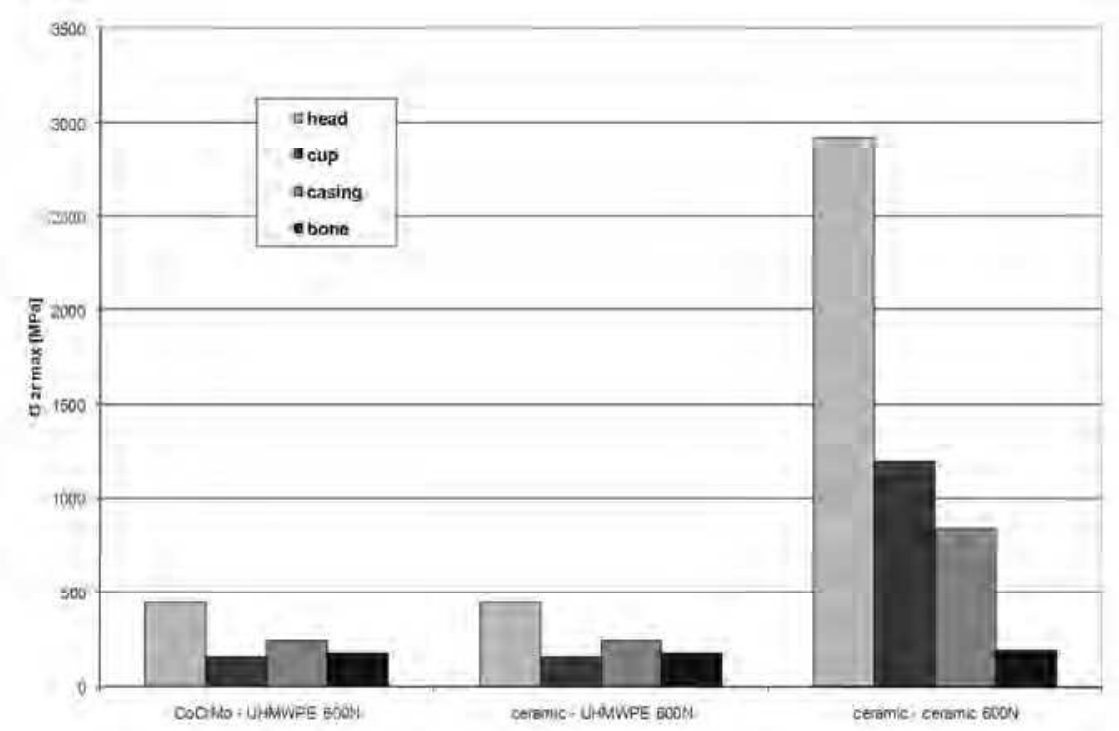

Fig. 4. Maximum stress values occuring in particular elements of set „head - cup - casing - bone" with load $600 \mathrm{~N}$

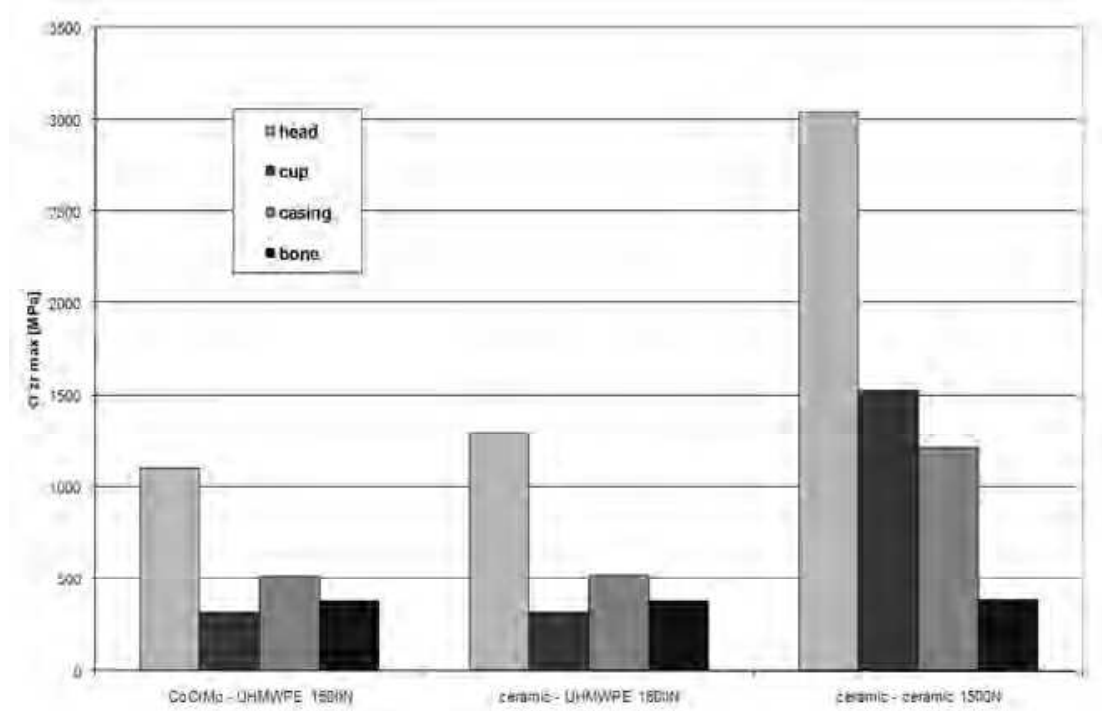

Fig. 5. Maximum stress values occuring in particular elements of set „head - cup - casing - bone" with load $1500 \mathrm{~N}$

Figure 5 presented maximum stress values occuring in particular elements of set: „head - cup - casing - bone”. Maximum stress values occuring in particular elements of set head cup casing is shown in Figure 6. 


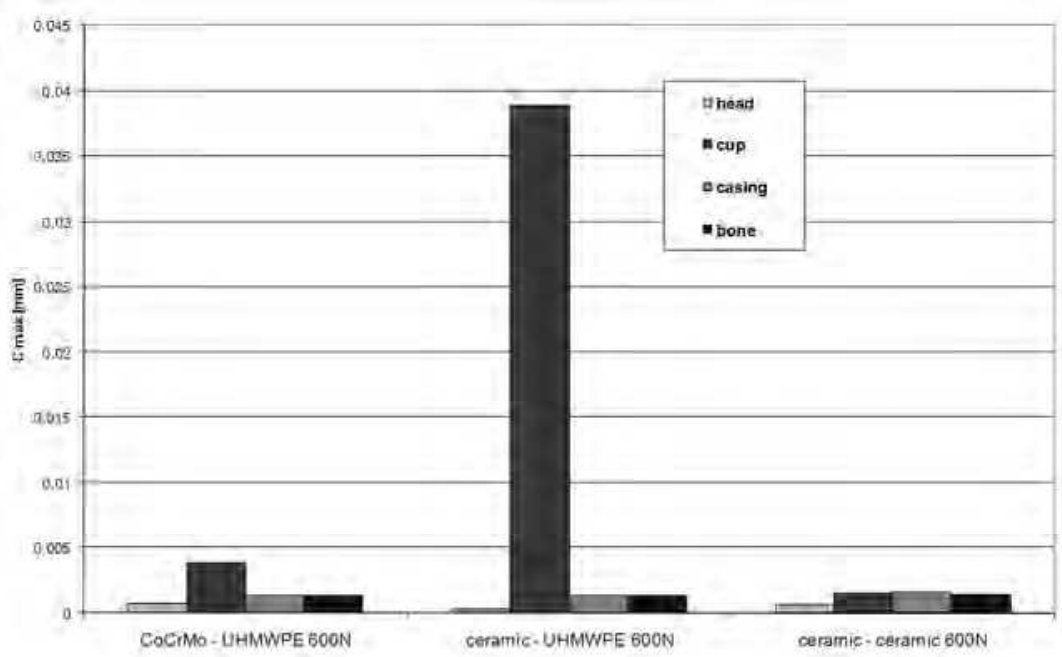

Fig. 6. Maximum stress values occuring in particular elements of set „head - cup - casing - bone" with load $600 \mathrm{~N}$

Figure 7 presents the maximum stress values occuring in particular elements of set: "head cup casing bone".

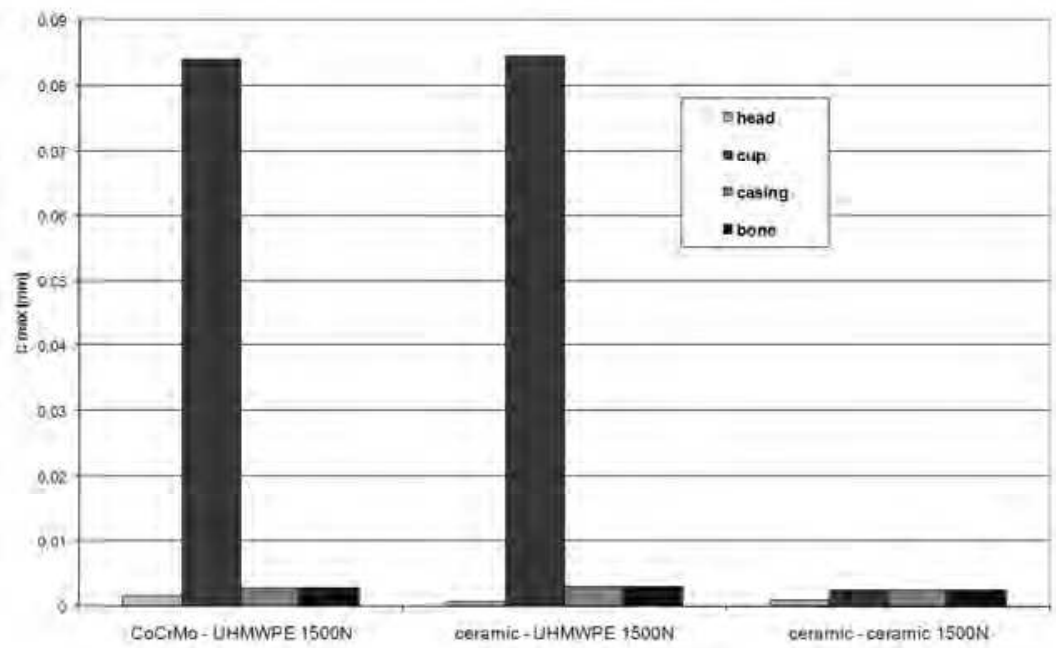

Fig. 7. Maximum stress values occuring in particular elements of set „head - cup - casing - bone" with load $1500 \mathrm{~N}$

The obtained results prove that the highest reduced stress values provide the set: bioceramic head - bioceramic cup. We should emphasise, that material features of cooperating elements cause a spot-butt between the surfaces. The stress is concentrated in the butt point and in the subsurface layer can reach even 3039 MPa with a load of $1500 \mathrm{~N}$. The set analysis shows that the stress is concentrated inside the 
head of endoprosthesis. Due to the contracts between the cooperating surfaces the stress is transferred onto the cups.

Much lower stress values were provided by the pair: ceramic head - cup UHMWPE. As the butt point of cooperating surfaces is different in this case, the obtained stress pattern varies as well. The strain covers a much bigger surface, therefore the stress has been transferred to deeper layers, not only onto the cup, but also onto its casing.

The lowest stress values were provided by the pair: the CoCrMo alloy head UHMWPE cup. In this case, the stress is also transferred through the polyethylene cup onto its casing.

In all of the cases the stress is concentrated in subsurface layer of the endoprosthesis head exactly in the area where the load is put into the set.

As the cup is replaceable and put inside the titanium casing, neither the stress is transferred nor are there any displacements from the endoprosthesis to the pelvis bone.

The highest strain occured in the cooperation between the ceramic head UHMWPE cup. With the highest load, the high strain of the cup was obtained and reached $0.084 \mathrm{~mm}$ in the surface area. Also deeper layers, like the cup casing suffered some strain.

The high strain of surface layer was also obtained in the case of polyethylene cup cooperating with the head made of CoCrMo alloy.

The otherwise case was of the pair: ceramic head - ceramic cup. The connection point between the cup and the casing was strained mostly, as well as was the pelvis bone.

\section{Geometrical model of knee joint endoprosthesis}

The analysed physical model of the knee joint ought to be respective to the real set as far as geometrical and material and load conditions are concerned. All simplifications should enable to conduct numerical simulation and achieve factual results.

Numerical analysis of tribological phenomena taking place in artificial joints allows one to see the wear process of UHMWPE polyethylene insert, used in knee joint endoprostheses, basing on a very simple wear model [13-15].

If we want to analyse contact strength or stress occuring in polyethylene insert, it is enough to construct a simplified model consisting of a metal sled and a polyethylene insert, which will let us settle the required values and analyse the phenomena occurring in the friction point of endoprosthesis.

The model presented in the paper consists which of the elements respective to all parts of the endoprosthesis: thigh, tibia, and polyethylene insert.

The analysis was conducted on the ADINA System 7.5.1. based on the finite elements method. It covered two types of inserts: spherical and flat. 
The finite elements mesh was built of 3600 cube-shaped elements of 3D Solid type and 4312 nodes.

Geometrical model of sled - spherical insert with the load and finite elements mesh is shown in Figure 8. Such discrete models of sleds and inserts were used to simulate the performance of polyethylene inserts under mechanical loads.

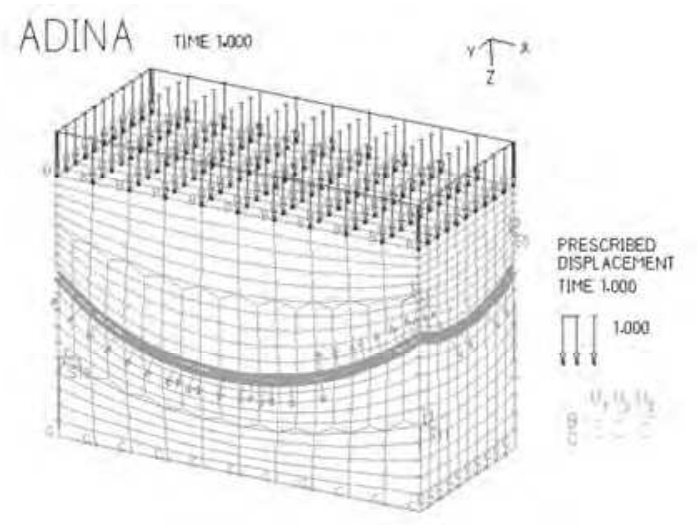

Fig. 8. Geometrical model of the set sled - spherical polyethylene insert. Finite elements mesh, load, degrees of freedom and contact area. General view

The finite elements mesh was built of 3200 cube shaped elements of 3D Solid type based on 3982 nodes.

\subsection{Data used for numerical calculations}

All issues of the stress pattern in the contact area of where the sleds are pressed onto the inserts, are based on the assumptions:

- Both contacted parts are made of isotropic material and obey Hook's law.

- The used load is close and relative to the one occuring in the real knee joint.

\subsection{Material data. The load model}

All calculations were conducted for flat inserts made of medical polyethylene with higher density (UHMWPE) and thickness: $8 \mathrm{~mm}$. In case of spherical inserts the typical ones were considered, offered by endoprostheses producers, with dimensions similar to flat inserts' of the same geometry.

Boundary conditions, settled for the calculations, are mechanical features of endoprostheses' elements as well as mechanical load distribution and values. It was assumed, that all materials used for models (medical titanium alloy Ti6Al4V, CoCrMo alloy, polyethylene UHMWPE) are linear-elastic and isotropic with constant mechanical features. The values of mechanical features, such as the resilience module and Poisson's coefficient are presented in Table 2. Simulations for the above cases of loads for given materials' physical features are set in the table below. 
Mechanical features and density of materials used for endoprostheses

\begin{tabular}{|c|c|c|c|}
\hline & $\begin{array}{c}\text { Young module E } \\
{[\mathrm{MPa}]}\end{array}$ & $\begin{array}{c}\text { Poisson's } \\
\text { coefficient } v\end{array}$ & $\begin{array}{c}\text { Density } \\
\rho\left[\mathrm{kg} / \mathrm{m}^{3}\right]\end{array}$ \\
\hline CoCrMo & $2.1 \times 10^{5}$ & 0.29 & 8300 \\
\hline Ti6A14V & $1.1 \times 10^{5}$ & 0.3 & 4500 \\
\hline UHMWPE & 1000 & 0.4 & 960 \\
\hline
\end{tabular}

The calculations take a standard and simplified model of the system load, where the load is put onto the upper surface of endoprosthesis sled.

\subsection{Stress and strain analysis for ,sled - flat insert" in the partial endoprosthesis and ,sled - spherical insert" in the Motta-Callea endoprosthesis}

The calculations were conducted for partial and total knee joint endoprosthesis. The most significant are reduced and contact stresses that occur in particular types of polyethylene inserts, due to the fact that the weakest kinematic point of endoprosthesis is UHMWPE polyethylene.

Contact stress pattern in flat and spherical polyethylene inserts is shown in Figures 9 and 10

Figure 11 presents the strain pattern of the material occuring under the surface of the flat polyethylene insert cooperating with the metal sled. The results of numerical calculations for particular geometrical models are presented in Figures 11, 12 and 13. The following values were taken for the analysis [16-18]:

- main stresses - $\sigma_{1}, \sigma_{2}, \sigma_{3}$,

- reduced stress Hubera-Misesa - $\sigma_{z r}$

- components of regular strain in direction of axis $\mathrm{x}-\varepsilon_{11}$,

$$
\begin{aligned}
& \sigma_{z r}=\sqrt{\frac{3}{2}\left(\sigma_{i j}-\sigma_{m} \delta_{i j}\right)\left(\sigma_{i j}-\sigma_{m} \delta_{i j}\right)}= \\
& =\frac{\sqrt{2}}{2} \sqrt{\left(\sigma_{1}-\sigma_{2}\right)^{2}+\left(\sigma_{2}-\sigma_{3}\right)^{2}+\left(\sigma_{3}-\sigma_{1}\right)^{2}}
\end{aligned}
$$

where: $\sigma_{m}=\frac{1}{3} \sigma_{i i}=\frac{1}{3}\left(\sigma_{1}+\sigma_{2}+\sigma_{3}\right)$ - average stress

For spatial (three-axis) state of stress, the stress tensor $\sigma_{i j}$ and strain tensor $\varepsilon_{i j}$ are: 


$$
\sigma_{i j}=\left[\begin{array}{lll}
\sigma_{11} & \sigma_{12} & \sigma_{13} \\
\sigma_{21} & \sigma_{22} & \sigma_{23} \\
\sigma_{31} & \sigma_{32} & \sigma_{33}
\end{array}\right], \quad \varepsilon_{i j}=\left[\begin{array}{lll}
\varepsilon_{11} & \varepsilon_{12} & \varepsilon_{13} \\
\varepsilon_{21} & \varepsilon_{22} & \varepsilon_{23} \\
\varepsilon_{31} & \varepsilon_{32} & \varepsilon_{33}
\end{array}\right],
$$

The stress may be presented as:

$$
\sigma_{i j}=C_{i j k l} \varepsilon_{k l}
$$

where $C_{i j k l}$ is the resilience tensor, defined as $[16,17]$

$$
C_{i j k l}=\frac{E}{2(1+v)}\left(\delta_{i l} \delta_{j k}+\delta_{i k} \delta_{j l}+\frac{2 v}{1-2 v} \delta_{i j} \delta_{k l}\right)
$$

The evaluation of the achieved results was based on stress and strain pattern in the section of particular models of endoprosthesis being analysed.

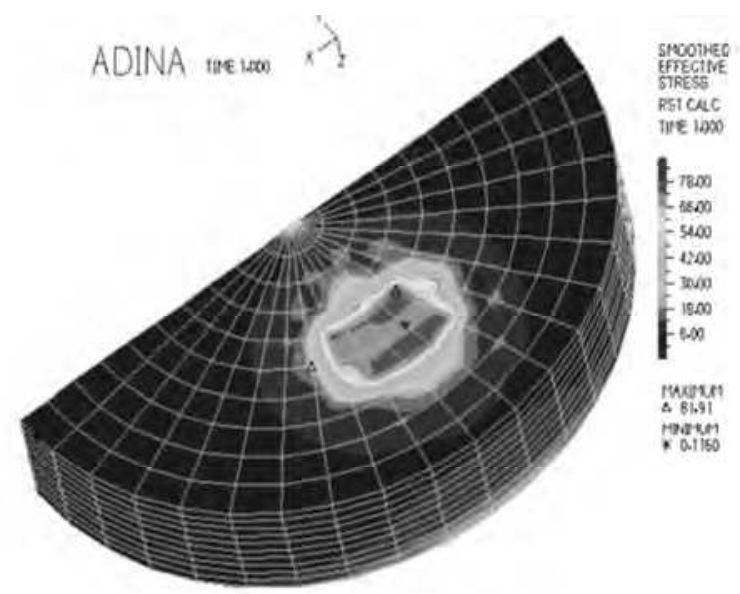

Fig. 9. Contact stress pattern in the flat polyethylene insert. General view of the model. The insert is $8 \mathrm{~mm}$ trick and cooperates with the sled of radius $27 \mathrm{~mm}$; load $1500 \mathrm{~N}$

The conducted calculations prove that the stress is concentrated in the polyethylene insert of the endoprosthesis, right under the surface of the contact point of both elements, where the area of highest stress is precisely visible right under the insert surface. The highest stress pattern is significantly different for flat and spherical inserts. The obtained tests results, confirming the theoretical thesis, proved that contact and reduced values of subsurface stress are higher for a flat insert than for a spherical one. Furthermore, the spherical inserts provide steady and equal stress pattern both contact and subsurface ones. 


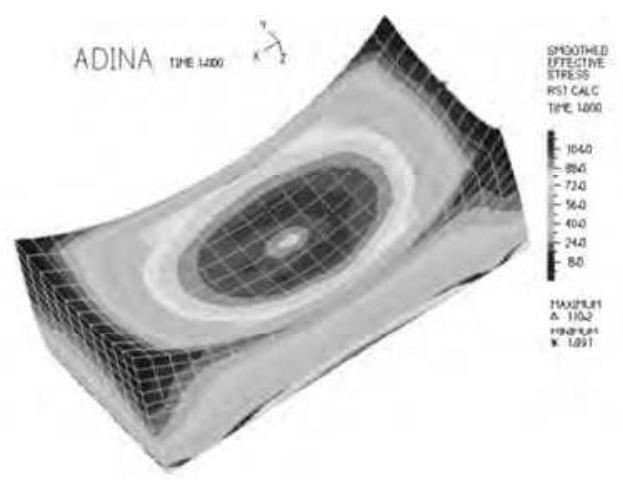

Fig. 10. Contact stress pattern in the spherical polyethylene insert. General view of the model. The insert is $8 \mathrm{~mm}$ trick and cooperates with the sled of radius $27 \mathrm{~mm}$; load $1500 \mathrm{~N}$

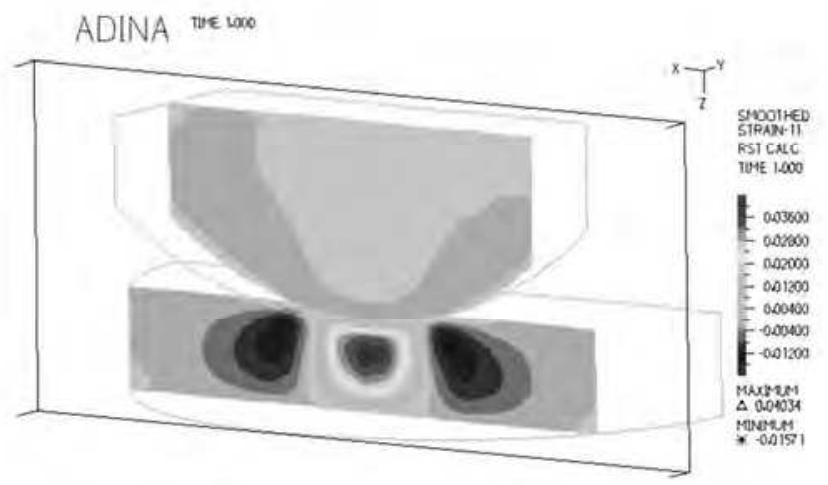

Fig. 11. Strain pattern of the material occuring under the surface of the flat polyethylene insert cooperating with the metal sled. The section of the model. Sled of the cross section radius $27 \mathrm{~mm}$; load $1500 \mathrm{~N}$

\subsection{Conclusions drawn from numerical simulations of knee joint endoprosthesis and concerning the stress pattern of the load carried by the implant:}

1. If the cooperating surfaces are properly adjusted to each other, and linear contact is substituted by a superficial one, the contact stress values are significantly lower.

2. Higher contact stress in the subsurface area is caused by a specific kind of friction pair the a sled - insert type. It is connected with destructive mechanism of the material, which delaminates especially in the last phase of the process.

3. The tests proved, that polyethylene insert of spherical type significantly influences the decrease of stress concentration and its even distribution; the conducted simulations confirmed the above. 


\section{References}

[1] Chi-Chung H., Jiann-Jong L., A two-dimensional finite element model for frictional heating analysis of total hip prothesis. Materials Science and Engineering C 2001, 17.

[2] Kreczko R., Orłoś Z., Tomaszewski K., Ocena wytrzymałości stawu biodrowego w oparciu o model obliczeniowy, Chirurgia Narządów Ruchu i Ortopedia Polska 1986, LI 4, 261-267.

[3] Ryniewicz A., Analiza mechanizmu smarowania stawu biodrowego człowieka, Uczelniane Wydawnictwa Naukowo-Dydaktyczne AGH, Kraków 2002.

[4] Scifert Ch.F., Brown T., Lipman J., Finite element analysis of a novel design approach to resisting total hip dislocation, Clinical Biomechanics 1999, 14, 697-703.

[5] http://www.aesculap.com

[6] http://www.atlas-hip.com

[7] http://www.wmt.com

[8] Katalog firmy Aesculap nr O -132.

[9] Ryniewicz A.M., Madej T., Analiza naprężeń i przemieszczeń w strefie roboczej endoprotezy stawu biodrowego, Mechanika w Medycynie nr 6, Rzeszów 2002, 127-134.

[10] Będziński R., Biomechanika inżynierska, Oficyna Wydawnicza Politechniki Wrocławskiej, Wrocław 1997.

[11] Krzesiński G., Zagrajek T., Modelowanie własności mechanicznych kości, Biology of Sport $1998,15,8$.

[12] Marciniak J., Biomateriały, Wydawnictwo Politechniki Śląskiej, Gliwice 2002.

[13] Gierzyńska-Dolna M., Biotribologia, Wydawnictwo Politechniki Częstochowskiej, Częstochowa 2002.

[14] Gierzyńska-Dolna M., Kubacki J., Specyfika zużycia endoprotez stawu biodrowego i kolanowego, Mat. II Sympozjum Inż. Ortop. i Prot. IOP’99, Białystok 1999, 45-51.

[15] Gierzyńska-Dolna M., Kubacki J., Wieczorek A., Tatar K., Mechanizm zużycia endoprotezy saneczkowej stawu kolanowego, Biology of Sport 1998, s. 112-119.

[16] Zakrzewski M., Zawadzki J., Wytrzymałość materiałów, Wrocław 1975.

[17] Zienkiewicz O.C., Metoda elementów skończonych, Wyd. Arkady 1972.

[18] Man M., Grabara J., Modrak V., Marginal cost of industrial production, PJMS 2011, 3. 
